\title{
Estrogen receptors in human disease
}

\author{
C. Cadenas $\cdot$ H. M. Bolt
}

Published online: 1 September 2012

(C) Springer-Verlag 2012

Many physiological processes are controlled by estrogen receptors, and their loss and overexpression may contribute to disease. Numerous xenobiotics mimic or antagonize estrogenic effects (Höfer et al. 2010; Romano et al. 2010, Bolt and Stewart 2011; Hengstler et al. 2011). In breast cancer, besides proliferation (Schmidt et al. 2008, 2009, 2011), immune cell infiltration (Schmidt et al. 2012), ERBB2 expression (Brase et al. 2010; Kammers et al. 2011; Petry et al. 2010), and antioxidative capacity (Cadenas et al. 2010), the estrogen receptor status also plays a critical role in prognosis and chemoresistance. Because of the central role of estrogen receptors in toxicology and human disease, the editors are pleased that Katherine A. Burns and Kenneth S. Korach from the National Institute of Environmental Health Sciences in North Carolina have contributed a comprehensive review on this cutting-edge topic (Burns and Korach 2012; this issue). Key messages are as follows:

- Positive estrogen receptor status is associated with better prognosis, because patients respond to antiestrogenic therapy. However, an exception is expression of a $36-\mathrm{kDa}$ variant of $\mathrm{ER} \alpha$, which is associated with worse survival and poor response to tamoxifen.

- Estrogen receptor levels are strongly controlled by miRNA. A well-documented example is the negative correlation between ER $\beta_{1}$ and miR-92.

- Endometriosis affects more than $10 \%$ of all women and leads to dysmenorrhea and infertility. Increased $\operatorname{ER} \beta$ levels and decreased $\operatorname{ER} \alpha$ levels have been shown, and $\operatorname{ER} \beta$ has been suggested as a therapeutic target.

C. Cadenas $(\bowtie) \cdot$ H. M. Bolt

Leibniz Institut für Arbeitsforschung an der TU Dortmund, Leibniz Research Centre for Working Environment and Human Factors (IfADo), Ardeystrasse 67, 44139 Dortmund, Germany e-mail: cadenas@ifado.de
- After menopause, prevalence of cardiovascular diseases increases in women to levels similar to those in men. While $\mathrm{ER} \beta$ seems to mediate myocardial protection, $\mathrm{ER} \alpha$ is responsible for protection against vascular diseases.

The comprehensive state-of-the-art review of Burns and Korach is highly recommended to anyone interested in the role of estrogen receptors in human disease.

\section{References}

Bolt HM, Stewart JD (2011) Highlight report: the bisphenol A controversy. Arch Toxicol 85(12):1491-1492

Brase JC, Schmidt M, Fischbach T, Sültmann H, Bojar H, Koelbl H, Hellwig B, Rahnenführer J, Hengstler JG, Gehrmann MC (2010) ERBB2 and TOP2A in breast cancer: a comprehensive analysis of gene amplification, RNA levels, and protein expression and their influence on prognosis and prediction. Clin Cancer Res 16(8):2391-2401

Burns KA and Korach KS (2012) Estrogen receptors and human disease: an update. doi:10.1007/s00204-012-0868-5; this issue

Cadenas C, Franckenstein D, Schmidt M, Gehrmann M, Hermes M, Geppert B, Schormann W, Maccoux LJ, Schug M, Schumann A, Wilhelm C, Freis E, Ickstadt K, Rahnenführer J, Baumbach JI, Sickmann A, Hengstler JG (2010) Role of thioredoxin reductase 1 and thioredoxin interacting protein in prognosis of breast cancer. Breast Cancer Res 12(3):R44

Hengstler JG, Foth H, Gebel T, Kramer PJ, Lilienblum W, Schweinfurth H, Völkel W, Wollin KM, Gundert-Remy U (2011) Critical evaluation of key evidence on the human health hazards of exposure to bisphenol A. Crit Rev Toxicol 41(4): 263-291

Höfer N, Diel P, Wittsiepe J, Wilhelm M, Kluxen FM, Degen GH (2010) Investigations on the estrogenic activity of the metallohormone cadmium in the rat intestine. Arch Toxicol 84(7): $541-552$

Kammers K, Lang M, Hengstler JG, Schmidt M, Rahnenführer J (2011) Survival models with preclustered gene groups as covariates. BMC Bioinformatics 12:478 
Petry IB, Fieber E, Schmidt M, Gehrmann M, Gebhard S, Hermes M, Schormann W, Selinski S, Freis E, Schwender H, Brulport M, Ickstadt K, Rahnenführer J, Maccoux L, West J, Kölbl H, Schuler M, Hengstler JG (2010) ERBB2 induces an antiapoptotic expression pattern of Bcl-2 family members in node-negative breast cancer. Clin Cancer Res 16(2):451-460

Romano RM, Romano MA, Bernardi MM, Furtado PV, Oliveira CA (2010) Prepubertal exposure to commercial formulation of the herbicide glyphosate alters testosterone levels and testicular morphology. Arch Toxicol 84(4):309-317

Schmidt M, Böhm D, von Törne C, Steiner E, Puhl A, Pilch H, Lehr HA, Hengstler JG, Kölbl H, Gehrmann M (2008) The humoral immune system has a key prognostic impact in node-negative breast cancer. Cancer Res 68(13):5405-5413

Schmidt M, Victor A, Bratzel D, Boehm D, Cotarelo C, Lebrecht A, Siggelkow W, Hengstler JG, Elsässer A, Gehrmann M, Lehr HA, Koelbl H, von Minckwitz G, Harbeck N, Thomssen C (2009) Long-term outcome prediction by clinicopathological risk classification algorithms in node-negative breast cancer-comparison between Adjuvant!, St Gallen, and a novel risk algorithm used in the prospective randomized Node-Negative-Breast Cancer-3 (NNBC-3) trial. Ann Oncol 20(2):258-264

Schmidt M, Petry IB, Böhm D, Lebrecht A, von Törne C, Gebhard S, Gerhold-Ay A, Cotarelo C, Battista M, Schormann W, Freis E, Selinski S, Ickstadt K, Rahnenführer J, Sebastian M, Schuler M, Koelbl H, Gehrmann M, Hengstler JG (2011) Ep-CAM RNA expression predicts metastasis-free survival in three cohorts of untreated node-negative breast cancer. Breast Cancer Res Treat 125(3):637-646

Schmidt M, Hellwig B, Hammad S, Othman A, Lohr M, Chen Z, Boehm D, Gebhard S, Petry I, Lebrecht A, Cadenas C, Marchan R, Stewart JD, Solbach C, Holmberg L, Edlund K, Kultima HG, Rody A, Berglund A, Lambe M, Isaksson A, Botling J, Karn T, Müller V, Gerhold-Ay A, Cotarelo C, Sebastian M, Kronenwett R, Bojar H, Lehr HA, Sahin U, Koelbl H, Gehrmann M, Micke P, Rahnenführer J, Hengstler JG (2012) A comprehensive analysis of human gene expression profiles identifies stromal immunoglobulin $\kappa \mathrm{C}$ as a compatible prognostic marker in human solid tumors. Clin Cancer Res 18(9):2695-2703 